\title{
Fuller and Arendt: A Happy Marriage? Comment on Rundle
}

\author{
Thomas Mertens
}

\section{Forms Liberate}

In her article on the need to develop a 'public legal theory through Fuller and Arendt', Rundle aims to develop further the theoretical thrust of her important book Forms Liberate by focusing on a more general question, namely how to develop a normative legal theory that is distinctively public or political. She aims to do so primarily by bringing Fuller into conversation with Arendt. In this comment, I want to add some caveats with regard to the viability of this conversation. Obviously, I am not claiming that Arendt's work could not or should not be brought into conversation with Fuller simply because Arendt never claimed to be a legal scholar. That is not a convincing argument at all. Yet, it is my conjecture that the position to which Rundle brings us in Forms Liberate leaves perhaps an insufficient basis for such a conversation. In brief, the gap that divides Arendt from Fuller in Rundle's reading might well be too large to bridge. In order to develop this claim, I shall rely to quite some extent on Rundle's book. The best way to start is its well-chosen title, which indicates at least three things.

Firstly, the title indicates the liberation of Fuller's jurisprudence from the narrow confines of the debate between Fuller and Hart, in which the latter had been able to set the jurisprudential agenda to the detriment of the former. Framing Fuller's position within this debate enabled Hart to interpret the eight criteria of what Fuller famously called the internal morality of the law in a merely instrumental way as compatible with a positivist outlook on law. According to Hart, law could be efficacious only if these eight requirements were observed. Consequently, there was nothing specifically 'moral' about them. Forms Liberate explicitly rejects such a distorted, 'checklist' reading of the eight requirements. Therefore, Fuller's jurisprudence had to be 'reclaimed' as an entirely different perspective on law - one which does not depart from a conception of political sovereignty from which subsequently legal commands or rules emanate. According to Fuller, Hart's concept of law, important as it may be, does not significantly differ from that of Austin. ${ }^{1}$ Whereas the positivist outlook basically conceives of law as a vertical enterprise, ${ }^{2}$ Fuller understands law according to Rundle as an intrinsically moral phenomenon and as 'a distinctive mode of governance,' which presupposes the legal subject's status as a responsible agent. The eight criteria are then needed to

1 Kristen Rundle, Forms Liberate. Reclaiming the Jurisprudence of Lon L Fuller (Oxford: Hart Publishing, 2012), 94.

2 Rundle, Forms Liberate, 129. 
establish and uphold the meaningful relationship between law and responsible human agency. ${ }^{3}$

This leads to the second meaning of Forms Liberate. Rundle ascribes to Fuller a view of law as a means for establishing human societies that are ruled in a way that respects the human agency of its members. Obviously, human societies can also be ruled, as is often the case, in a managerial way by men. Thus, according to Fuller, the rule of law is 'a formally recognizable alternative to the rule of men.' Whereas the latter indicates the mode of a managerial direction whose subjects are conceived as, in Rundle's words, 'a subservient populace ready to do what they are told to do,' the former points at a social condition in which a person is respected as 'a responsible agent.' In other words, law's forms liberate in the sense that they establish according to Fuller a meaningful relationship between law and human agency. Law should not be associated, as is the case in the positivist approach, with a managerial approach to society and a top-down, vertical relationship between lawgiver and legal subjects. In line with its 'idealistic tenor, ${ }^{5}$ Rundle understands Fuller's approach to law as requiring - or perhaps better: presupposing - a horizontal relationship of reciprocity between lawgiver and legal subjects. This then is the meaning of 'the internal morality of law,' Fuller's central contribution to legal theory: in order for legal rules to be created and administered in a manner that respects the human agency of the legal subjects, they must be general, promulgated, clear, non-contradictory, non-retroactive etc. If the law does not meet these requirements, it violates human agency and belongs to what Fuller, in Rundle's words, called 'legal pathology. ${ }^{6}$ It is therefore wrong to understand these criteria, as Hart did, as non-moral requirements for the efficacy of law. Instead, they are per excellence the moral requirements of making and upholding the distinct way of governing human societies that is properly called 'law.'

In a third and final sense, Forms Liberate forms a plea for another kind of legal scholarship that liberates itself 'from its preoccupation with source-based imperative theories and their instrumentalist commitments,' i.e. from the need to identify rules as 'legal' rules 'by reference to some source-based test,"7 either in the form of a sovereign will or in the form of a supposedly natural law. ${ }^{8}$ According to Rundle, legal scholarship must move away from the deadlock of the source oriented, 'top-down oriented' and 'unidirectional'9 debate between positivism and non-positivism and instead focus on how law arises out of 'reciprocal' ${ }^{10}$ relationships both among citizens themselves and between lawgivers and their legal subjects. As the eight criteria give expression to the idea of human agency, they

3 Rundle, Forms Liberate, 2-3.

4 Rundle, Forms Liberate, 139.

5 Rundle, Forms Liberate, 4.

6 Rundle, Forms Liberate, 81, 94.

7 Rundle, Forms Liberate, 49, 77, 119.

8 See, e.g., Rundle, Forms Liberate, 31, 44.

9 Rundle, Forms Liberate, 122, 125.

10 Rundle, Forms Liberate, 89, 122. 
provide the necessary starting position to establish a jurisprudence that is radically distinct from the view that law has essentially 'a pyramidal structure.'11

\section{Fuller's society}

Fuller's jurisprudence has thus been reclaimed against Hart's efforts to integrate the eight principles into a positivist account of the law, and an alternative picture arises of a society whose subjects are not acted upon but treated as responsible agents, i.e. governed through law. ${ }^{12}$ This society is supposedly held together by laws and regulations that stem from reciprocal relationships between lawgivers and legal subjects - relationships characterized by concepts such as trusteeship, dialogue, respect and dignity.

This all sounds admirable and worth pursuing, but also quite utopian. A Fullerian society seems far removed from the everyday, 'empirical' life of the law in our societies, in which positive law is the result of and characterized by political struggles. It thus seems as if Fuller's 'idealistic' conception of law as enabling and guaranteeing agency indeed needs to be complemented by a political dimension: how to acknowledge and deal with the fact that law is so related to political power that it makes its association with 'coercion and sanctions'13 so convincing. This then must be Rundle's direction forward: a view of politics that is not centred on sovereignty as the source of law structured as a pyramid, but around human agency as in Fuller's view of law. I presume that this has led Rundle to Arendt's political philosophy; Arendt's work can provide inspiration for how to establish and to uphold such dialogical relationships between lawgivers and legal subjects.

And there seem to be good reasons for bringing Fuller together with Arendt. Both authors defend rather unorthodox approaches: Fuller does not fit into the dominant jurisprudential distinction between positivism and non-positivism. Arendt also does not fit into any common political scheme: neither into the liberalcommunitarian distinction, nor into the simple division between political right or left. Both Fuller and Arendt hold independent positions within law and political philosophy respectively, with similar shortcomings: Fuller's focus on law seems to neglect its political dimension, whereas Arendt's political analyses seem to underestimate the importance of law. Therefore Fuller and Arendt seem to complement each other: why not tease out their common interest in the legal subject and the juridical person respectively?

In examining the extent to which such a conversation can be fruitful, we can perhaps start with the fact that Forms Liberate acknowledges that no rigid opposition exists between the rule of law with its recognition of human agency on the one hand and managerial direction addressed at subservient populations on the

11 Rundle, Forms Liberate, 93.

12 Rundle, Forms Liberate, 98-99.

13 Rundle, Forms Liberate, 94. 
other. ${ }^{14}$ The difference between the two forms of governance, the rule of law and legal pathologies, is often a matter of degree. Yet, it is not fully clear what are the political conditions under which societies can move away from 'managerial direction' to the 'rule of law' (or vice versa), and whether the rule of law sets constraints on the kind of purposes societies can attain, including the type of purposes that are excluded.

If Fuller's jurisprudence does indeed lack a substantial political element, this is how to understand Rundle when she writes that his conception of the person should not be understood as prior to the law, but rather as something that 'arises

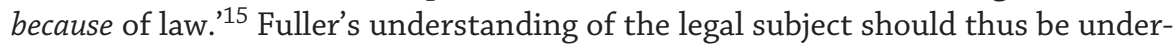
stood in connection with a particular surrounding legal and political order. ${ }^{16}$ This is perhaps best illustrated by Fuller's story of the tyrant. According to Forms Liberate, the tale of the tyrant who uses his subjects as tools but inadvertently must accord them some agency, suggests that tyrannical forms of managerial direction inevitably and inadvertently lead to legal forms and thus to agency. Tyrants may aim only to use society for their own ends, but they must inevitably make use of 'legal forms' by means of which the tyrant's subjects gradually become liberated from his tyranny and develop agency. Despite the tyrant's explicit aims, legal forms defeat him as a tyrant. ${ }^{17}$ But if that is the case, than it would seem that the forms of law themselves are sufficient to liberate subjects from managerial direction and bestow upon them 'agency.' Why is Arendt still needed? Is the tale of the tyrant not convincing after all or is the use of legal forms alone not enough to defeat tyranny and to establish the rule of law that fully recognizes human agency?

\section{Arendt and the law}

In her paper, Rundle rightly stresses Arendt's interest in the juridical person and in human agency in general. According to Arendt, there is hardly anything more important in human life than being recognized as a juridical person; Arendt conceives of the right to have rights as the single most important human right. ${ }^{18}$ Without this right, human beings are cut off from the political world and become the objects of, in Fuller's words, arbitrary 'managerial direction,' living at the discretion of the powers that be. One could indeed argue that being recognized as a juridical person is for Arendt the precondition for human agency. Rundle refers to the crucial distinction within the concentration camps between 'the criminals' and 'the politicals' which hinges on the fact that the former were locked up for

15 Kristen Rundle, 'Legal Subjects and Juridical Persons: Developing Public Legal Theory through Fuller and Arendt,' this volume, 222 (italics hers).

16 Rundle, 'Legal Subjects and Juridical Persons,' 214.

17 Rundle, Forms Liberate, 109.

18 Hannah Arendt, The Origins of Totalitarianism (London: Harcourt Brace, 1958), 290-302. 
what they had done and the latter for who they were. The agency of the former was still acknowledged, while the agency of the latter completely denied.

In Rundle's view, Arendt's reluctance to engage with law and legal theory is the result of her interest in developing an alternative account of law. Both Fuller and Arendt are said to put forward 'strident critiques of the command theory of law. ${ }^{19}$ Therefore, it seems safe to suppose, according to Rundle, that Arendt also rejects any source-based account of the law. Rundle attributes to Arendt the view that law and its institutional forms (should) constitute 'a distinctive species of personhood vis-à-vis political power. ${ }^{.20}$ According to Rundle's reading of Arendt, a person should indeed never become merely an instrument of political power, but should always sustain its legal status as a person.

Nonetheless, the question must be asked as to whether Arendt conceives of personhood as somehow entailed or implied in the concept of 'law,' as seems to be the case in Fuller; or whether personhood is for Arendt a moral requirement to the law, inspired by her republican approach to politics. As this requirement is often not met, her contemporary political landscape (and ours) consisted of nation-states with an exclusive power to decide who belongs and who not. In other words, whether Fullerian views can be brought into conversation with Arendt, depends to a large extent on what conception of law and political person emerges from the texts in which Arendt engages most explicitly with law and legal theory.

Rundle presents us with some forceful examples of how Arendt can indeed be read fruitfully from a Fullerian perspective. Yet, there is also a forceful counterexample and it is Arendt's most 'legal' treatise: her report on the Eichmann trial. It is remarkable that Rundle does not confront her interpretation of Fuller with this text, for here, Arendt deals explicitly with questions concerning both the rule of law and the source of the law, i.e. the law on which the jurisdiction of the Jerusalem court could be based. Study of this text suggests that Arendt's views fit badly with the way Rundle in which conceives of law in opposition to managerial direction. In her report on the Eichmann trial, Arendt not only explicitly affirms the legitimacy of the trial and its outcome - conviction and execution - but she also accepts the violations, at least formally, of the rule of law. This seems incompatible with Fuller who forcefully wrote: 'every departure from the principles of law's inner morality is an affront to man's dignity. To judge his actions by unpublished or retrospective laws (...) is to convey to him your indifference to his powers of self-determination. ${ }^{21}$

19 Rundle, 'Legal Subjects and Juridical Persons,' 216.

20 Rundle, 'Legal Subjects and Juridical Persons,' 218.

21 Lon L. Fuller, The Morality of Law (revised edition) (New Haven: Yale University Press, 1969), 162. 
This point cannot be fully elaborated here. ${ }^{22}$ However, even a quick glance at Arendt's report shows that she was (1) not particularly worried by the trial's violation of the rule of law and (2) that she was interested in the source of the Jerusalem's jurisdiction. Starting with the last element: Arendt took a keen interest in the legal discussions concerning the authority of the law under which Eichmann was tried, convicted and punished. In defence of the jurisdiction of the Jerusalem court, some had argued in favour of the 'passive personality' principle. Arendt rejected this basis because it would bring the trial too close to the perspective of harm done to the victims, whereas a criminal trial should, as she saw it, revolve around the question of whether the accused had violated a legal norm. Arendt also rejected 'universal jurisdiction' as the source of the legitimacy of the court: 'universal jurisdiction' had been granted in relation to the crime of piracy because that crime took place on the open sea, where the territoriality principle could not apply. For Arendt, since Eichmann's crimes had taken place on a specific territory, namely where the Jews resided, the correct answer to the question of the jurisdiction of the court should lie in the principle of 'territoriality,' even if the 'residents' of this territory could not claim citizenship of their own state. In other words, although the State of Israel was established only later, it could legitimately claim jurisdiction ex post. The fact that the State of Israel did not have a territory when Eichmann committed his crimes because it did not yet exist, does not bar its jurisdiction.

The importance for our purposes here is not whether Arendt's 'solution' to the problem of the jurisdiction of the Jerusalem court is correct or convincing, but the fact that she finds it important to indicate the legal source for this jurisdiction and that she is not concerned that this might be seen as a possible violation of the rule of law. The argument that the whole trial was a sham trial and a violation of the rule of law was made by the defence, but Arendt was not impressed. For her, the Eichmann trial was not just politics with invented legal means, but it was law indeed, because the State of Israel had the right to prosecute Eichmann.

In relation to the first element, we find that Arendt attributes authority to the Jerusalem law, even if it violates formal requirements of the rule of law. This is relevant because Rundle stresses Fuller's words that 'every departure from the principles of law's inner morality is an affront to man's dignity as a responsible agent. ${ }^{23}$ It was argued on Eichmann's behalf that not only the prosecuting State of Israel, but also the law itself under which Eichmann was tried (the 1950 Israeli 'Nazis and Nazi Collaborators (Punishment) Act'), was being applied to him retroactively, so that the trial would testify of, in Fuller's words, 'indifference to his [Eichmann's] powers of self-determination.' Arendt, however, famously argued that the prohibition of non-retroactive legislation has validity only with regard to crimes that the legislator could reasonably have foreseen. In her view, it would be absurd to argue that the unprecedented crime of the Holocaust could not be pun-

22 See, e.g., Thomas Mertens, 'The Eichmann Trial: Hannah Arendt's View on the Jerusalem Court's Competence,' German Law Journal 6 (2005), 407-24. 
ished because it was an entirely new crime, and thus not foreseen by any legislator. She held that the demands of material justice cannot be set aside out of deference for formal considerations of temporality and retroactivity. The introduction of this new, retroactive law was justified, according to Arendt, even if it were to be construed as a violation of Eichmann's agency.

This leads to the final element which makes it difficult to unite Fuller's view of law with Arendt's interpretation of the Eichmann report. There has been ample debate on Arendt's portrayal of Eichmann as a banal person who did not realize what he was doing. There is sufficient evidence today that Eichmann was not a mere civil servant, but that he held strong anti-Semitic convictions and that he knew very well what he was doing. ${ }^{24}$ Arendt may thus have been wrong in arguing that Eichmann lacked mens rea, i.e. that he committed his crimes under circumstances that made it 'well-nigh impossible for him to know or to feel that he was doing wrong. ${ }^{25}$ Yet, it is not always fully appreciated that Arendt wholeheartedly supported Eichmann's conviction and the death penalty despite her assessment of his lack of intentionality. Apparently, Eichmann's intentions and motivations - his supposed lack of 'agency' - was irrelevant to Arendt. Instead, what was crucial was Eichmann's central role in this great crime. According to Arendt, the Holocaust was an offence against nature, in which the earth cried out for revenge. ${ }^{26}$ For Arendt, Eichmann deserved to die because the law of nature so demanded it. The prohibition on retroactive criminal legislation could not shield the punishment of acts that were clearly and evidently, by nature, ${ }^{27}$ criminal.

Rundle's attempt to bring Arendt to the aid of Fuller in challenging the command theory of law opens interesting vistas, but also faces serious challenges. In her report of the Eichmann trial, Arendt relies on a conception of law that profoundly differs from Fuller's. She acknowledges that the prevailing criminal laws leave us rather empty-handed when dealing with the new crimes against humanity, but these crimes must nonetheless be punished, even if adjudicating them means violating the internal morality of the law.

\section{Radbruch}

If Fuller and Arendt do not make an ideal couple, where can we go from here? I want to end this comment with a suggestion for a direction that Rundle may wish to explore: rather than pairing Fuller with Arendt, it may be more fruitful to connect Arendt's views with the legal philosophy of Gustav Radbruch, the wellknown German philosopher whose response to certain post-war cases formed

24 David Cesarani, Eichmann. His Life and Crimes (London: Vintage, 2005); Bettina Stangneth, Eichmann vor Jerusalem: Das unbehelligte Leben eines Massenmörders (Zürich/Hamburg: Reinbek, 2011).

25 Hannah Arendt, Eichmann in Jerusalem. A Report on the Banality of Evil (New York: Penguin, 1994 (1963)), 276.

26 Arendt, Eichmann in Jerusalem, 277.

27 Arendt, Eichmann in Jerusalem, 277. 
part of the debate between Fuller and Hart. Elsewhere I have argued that Fuller certainly had the better argument in relation to Radbruch's famous post-war essays because he, and not Hart, clearly understood what was at stake. ${ }^{28} \mathrm{I}$ wish to suggest that, in regard to the Eichmann trial, Arendt's position is better illuminated by Radbruch, who famously defended that claims of legal certainty - and thus of human agency - should be set aside in extreme cases if the demands of (criminal) justice so require.

Radbruch presents us with a rich philosophy of law. His central 'idea of law' includes not only, under the heading of legal certainty, the formal criteria of lawmaking that Fuller emphasizes, but also the substantive criteria of 'justice' and 'purposiveness.' As a result of this last component, the realm of competing ethical and political values forms part of 'the idea of law.' Radbruch is well aware that law does not function within a political vacuum; it is always (also) a means, an instrument by which (groups of) legal subjects aim to realise particular values. For some, the ultimate value may reside in the greatest possible freedom for each individual member of society, while for others it exists in the well-being of society as a whole. By acknowledging 'purposiveness' as part of the 'idea of law,' Radbruch succeeds in understanding law as resulting from the political struggle between opposing groups with different views on what values and purposes should be promoted by society. Because legal certainty is another important element of the 'idea of law,' these values and purposes can only be achieved legally when human agency is respected. ${ }^{29}$

In his post-war essays, Radbruch criticizes so-called Nazi-legality, but not only as is often said because of its clear violation of 'justice as equality,' but also because of its violation of legal certainty. Indeed, according to Radbruch's formula, legal certainty can sometimes be set aside in favour of justice. However, the importance that Radbruch, as Fuller, attributes to legal certainty and human agency should not be overlooked. At the end of his most famous post-war essay, Radbruch insists on the importance of legal certainty, writing that 'we must seek justice, but at the same time attend to legal certainty, for it is a component of justice. ${ }^{30}$ Legal certainty, with its emphasis on forms, sets clear limits to how societal purposes and values can be reached legally.

Radbruch did not conceive of law, as Fuller did, as a dialogue between lawgiver and legal subjects. For Radbruch, law cannot be isolated from the political because its material content is derived from politics. 'Managerial direction' can therefore not be isolated from the life of the law. It is not easy to find ways in which to (2002), 186-205.

29 See, e.g., Gustav Radbruch, Rechtsphilosophie (ed. Erik Wolf) (Stuttgart: K. F.Koehler, 1970 (1932)), Par. 9, 168-73.

30 Gustav Radbruch, 'Gesetzliches Unrecht und Übergesetzliches Recht (1946),' in Radbruch, Rechtsphilosophie, 357; translated as: Gustav Radbruch, 'Statutory Lawlessness and Supra-Statutory Law,' trans. Bonnie Litschewski Paulson and Stanley L. Paulson, Oxford Journal of Legal Studies 6 (2006), 11. 
harmonize the claims of law and of politics, and Radbruch even used the concept of antinomy to characterize their relationship. However, he attempted to provide some guidance to understanding it: whereas law itself cannot decide which societal values and purposes should be promoted, it sets constraints on how these purposes should be realized, namely only by respecting the claims of legal certainty. The law should also, according to Radbruch, determine the process by which societal purposes are selected. Since neither science nor philosophy can decide on the truth of the values or purposes presented in the political arena - in this respect, Radbruch is a relativist - it should be the democratic process that ultimately determines the outcome of the political struggle. Rather than developing a political perspective that complements the legal forms, as Rundle suggests, Radbruch presents us with an 'idea of law' that aims to give both the legal and political perspective its legitimate limited place. This sounds very much like Arendt's analysis of the Eichmann trial from both the political and the legal perspective. 